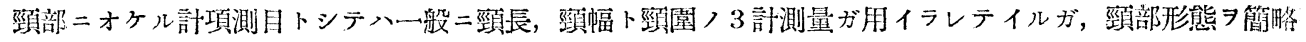
二數式化シタイト思ツテーツノ型式郎チ项式ヨ考案シタ。而シテュノ型式ヨ定メルタメノ計測項目トシテ上 記ノ 3 計測量ノ他二更 $=3$ 個ノ計測量 $习$ 追加シタ，即チ

1. 頸長：次ノョウナ色ณナ方法ガアゲラレテイル。

i）耳後）乳樣哭起外面中央カラ鎻骨中央二到ル距離デ左右別及二卷尺デ計測シテッノ本均习頸長卜スル 法,

ii）鼻下點高カラ胸骨上緣高ヨ引イテ得タ投射尺度ヨ頸長トスル方法.

iii）胸骨上點 [sst] カラ頸澅汽ノ值線距離ジ桿狀兩脚器デ測ル法.

iv）願高カラ肩峰高习引イテ得夕投射己度习頸長トスル法.

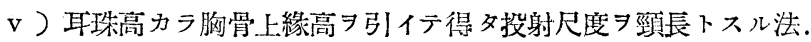

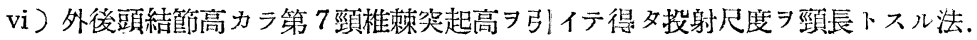

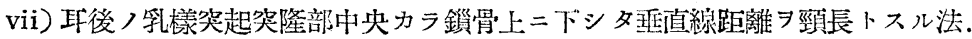

以上ノ計測法ノウチ最後ノvii) 7 用イ投射計測法ニョッタ.

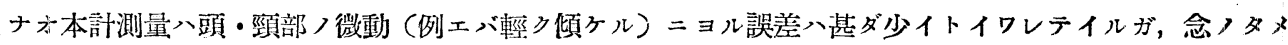

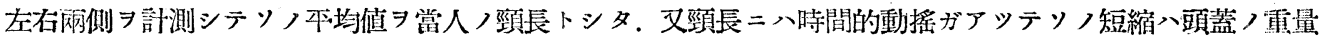
ニョル頸部ノ椎間板, 壓縮サレルタメデ, ソノ短縮、多クハ午前中二完了シ, 年命二反比スルトイワレティ ルノ汭計測ハスペテチ後ニ行ツタ.

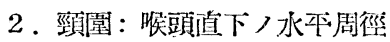

3. 顽幅 I：左右兩乳樣哭起哭隆部中央間，㨁線距離.

4. 頸幅 II : 頸園ノ高サニ一致シタ部ノ左右徑デ，一般ニ八單二頸幅又八頸左右徑トイワレティル。

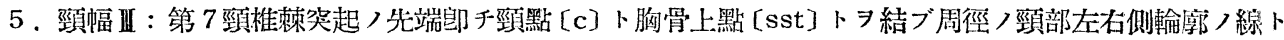
交ワル點間八直線距離.

6. 䣆深：頸園ノ高サ二一致シタ部ノ前後徑.

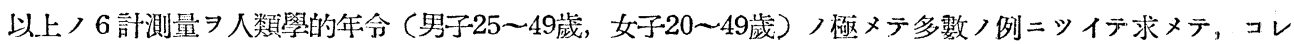

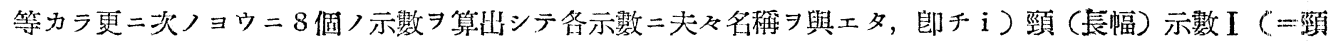

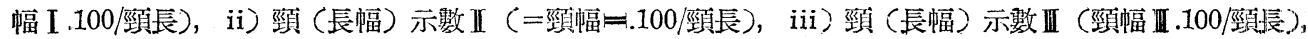

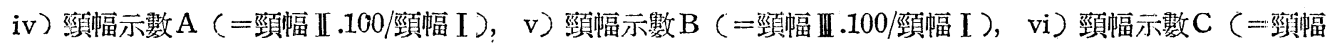

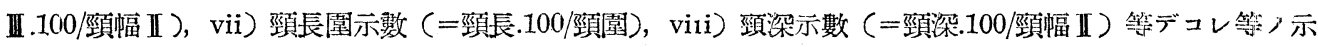

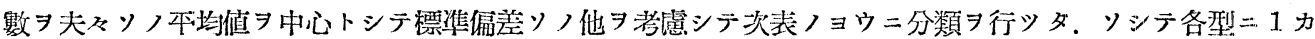

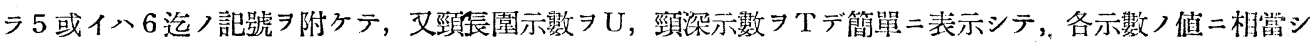

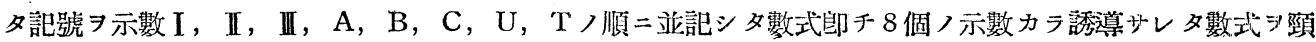
式ト名付ケタ。ナオコノ分類ヨ行ウニアタッテ用イタ材料ハ口帶式ノ時ト同ジクスベテ東京都及ビソ〉近倍 ニ居住スルモノノミデアル。

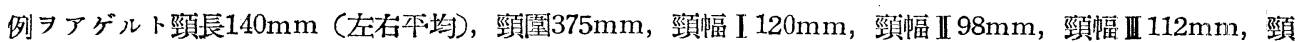
深93mmナル43歲男子八钼示數 I 85, 71, 同示數 II 70.00, 同示數 II 80.00, 莖幅示數 A 81.67, 同示數B 93.33 ,

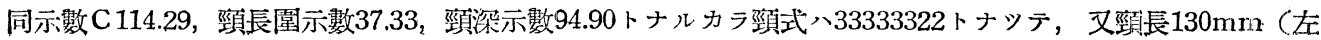




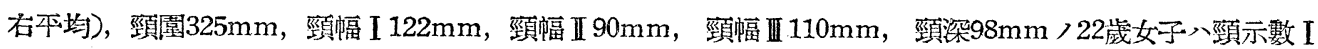
93.85, 同示數 II 69.23, 同示數 II 84.62, 项幅示數 $\mathrm{A} 73.77$, 同示數 B90.16, 同示數 C 122.22 , 頚長園示數 40 . 00 , 頸深示數108.89トナッテ43323433ナル頸式 呈シテイルコトニナル.

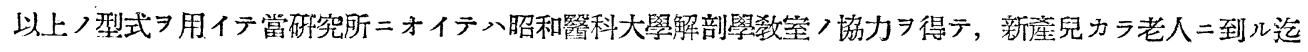

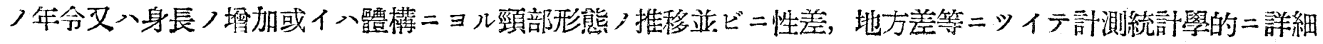
ナ硎究习淮メティル。

莖示示数 I（頸幅 I.100/頸長）

\begin{tabular}{|c|c|c|}
\hline 類 & 訩 號 & 境 \\
\hline 過炏䣆上型 & 1 & $\mathrm{X} \sim 69.9$ \\
\hline 犹 頸 上 型 & 2 & $70.0 \sim 79.9$ \\
\hline 中 頸 上 型 & 3 & $80.0 \sim 89.9$ \\
\hline 廣 靧 上型 & 4 & $90.0 \sim 99.9$ \\
\hline 過廣頸上型 & 5 & $100.0 \sim X$ \\
\hline
\end{tabular}

頸示數 II（頝幅 II.100/頚長）

\begin{tabular}{|c|c|c|c|c|}
\hline 類 & 訅 號 & 境 & 界 & 值 \\
\hline 過 狹長 頸 型 & 1 & & $\sim 52.9$ & \\
\hline 狹 長 頸 型 & 2 & 53 & $0 \sim 62.9$ & \\
\hline 中 頸 型 & 3 & & $0 \sim 72.9$ & \\
\hline 廣 短 䫇 型 & 4 & & $0 \sim 82.9$ & \\
\hline 過 廣 短靧型 & 5 & & $0 \sim X$ & \\
\hline
\end{tabular}

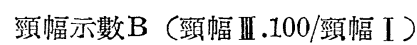

\begin{tabular}{|c|c|c|}
\hline 類 & 記 號 & 境 \\
\hline 過 渎 小頸 型 & 1 & $x \sim 79.9$ \\
\hline 狄 小頸 型 & 2 & $80.0 \sim 89.9$ \\
\hline 中 頸 型 & 3 & $90.0 \sim 99.9$ \\
\hline 廣大頊 型 & 4 & $100.0 \sim 109.9$ \\
\hline 過廣大頸型 & 5 & $110.0 \sim X$ \\
\hline
\end{tabular}

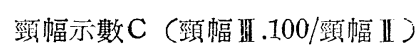

\begin{tabular}{|c|c|c|}
\hline 類 & 訅 號 & 璫 \\
\hline 過 小葝下型 & 1 & $X \sim 101.9$ \\
\hline 小 䣆 下 型 & 2 & $102.0 \sim 111.9$ \\
\hline 中 頸下型 & 3 & $112.0 \sim 121.9$ \\
\hline 大頸下型 & 4 & $122.0 \sim 131.9$ \\
\hline 過大䣆 下型 & 5 & $132.0 \sim 141.9$ \\
\hline 超大靧下型 & 6 & $142.0 \sim X$ \\
\hline
\end{tabular}

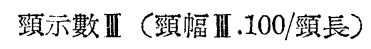

\begin{tabular}{|c|c|c|c|c|}
\hline 類 & 訅 號 & 境 & 界 & 值 \\
\hline 過 猂頸下型 & 1 & & $\sim 66.9$ & \\
\hline 狹 頙 下 型 & 2 & 67 & $0 \sim 76.9$ & \\
\hline 中 頸下 型 & 3 & & $0 \sim 86.9$ & \\
\hline 廣 頸 下 型 & 4 & & $0 \sim 96.9$ & \\
\hline 過廣型下型 & 5 & & $0 \sim X$ & \\
\hline
\end{tabular}

頸幅示數A（䫇幅 II.100/㲁幅 I )

\begin{tabular}{|c|c|c|c|c|}
\hline 類 & 記 號 & 境 & 界 & 值 \\
\hline 過大頸上型 & 1 & & $\sim 66$ & \\
\hline 大 䁰 上 型 & 2 & & $.5 \sim 76$. & \\
\hline 中 靧 上型 & 3 & & $.5 \sim 86$. & \\
\hline 小頸 上 型 & 4 & & $.5 \sim 96$. & \\
\hline 過 小頸上型 & 5 & & $5 \sim X$ & \\
\hline
\end{tabular}

靧長園示數 (頸長.100/頞圍)

\begin{tabular}{|c|c|c|c|c|}
\hline 類 & 訑 號 & 境 & 界 & 值 \\
\hline 過大䣆圍型 & 1 & & $\sim 32.9$ & \\
\hline 大 頸 圍 型 & 2 & & $.0 \sim 37.9$ & \\
\hline 中 靧 圍 型 & 3 & & $.0 \sim 42.9$ & \\
\hline 小 勔 圍 型 & 4 & & $.0 \sim 47.9$ & \\
\hline 過 小頸圍型 & 5 & & $0 \sim X$ & \\
\hline
\end{tabular}

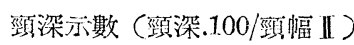

\begin{tabular}{|c|c|c|c|c|}
\hline 分 & & 類 & 訑 號 & 漟 \\
\hline & 淺 頸 & 型 & 1 & $x \sim 90.9$ \\
\hline & 頸 & 型 & 2 & $91.0 \sim 100.9$ \\
\hline & & 型 & 3 & $101.0 \sim 110.9$ \\
\hline & 㶾 & 型 & 4 & $111.0 \sim 120.9$ \\
\hline & 深 靧 & 型 & 5 & $121.0 \sim X$ \\
\hline
\end{tabular}


1) Height of the zone of the mouth: the direct distance from the gnathion to the subnasale.

2) Height of all the lips: the direct distance from the mentolabial sulcus to the subnasale.

3) Height of the mucous membrane of the mouth: the direct distance from the labrale inferius to the labrale superius.

4) Height of all the upper lips: the direct distance from the stomion to the subnasale.

5) Height of all the lower lips: the direct distance from the mentolabial sulcus to the stomion.

6) Height of the lower face: the direct distance from the gnathion to the stomion.

7) Width of the aperture of the mouth: The direct distance between the right and left sides of the cheilion.

8) Width of the submaxillary angle: the direct direct distance between the right and left sides of the gonion.

From the above eight quantitative measurements, the following eight indices were derived:

i) Lip-index I (=height of all the lips. 100/height of the zone of the mouth).

ii) Lip-index II (=height of all the upper lips. 100/height of the zone of the mouth).

iii) Lip-index III (=height of all the lower lips. 100/height of the zone of the mouth).

iv) Lip-height index A (=height of all the upper lips. 100/height of all the lips).

v) Lip-height index B (=height of all the lower lips. 100/height of all the lips).

vi) Lip-height index C (=height of all the lower lips. 100/height of all the upper lips).

vii) Index of the mucous membrane of the mouth $(=$ height of the mucous membrane of the mouth. 100/width of the aperture of the mouth).

viii) Index of the lower face $(=$ height of the lower face. $100 /$ width of the submaxillary angle).

These indices were sought from the anthropological ages of many instances of men and women, and centered around their respective arithmetical averages, these indices were classified into six types taking into consideration standard variations and other factors.

These types were symbolized simply from one to six, and by using the letters "MS" for the index in vii) above and the Ietters " $U G$ " for the index in viii) above, the numerical formula which was produced by charting the indices parallely in the order of I II III A B C MS UG was named the Formula of the Zone of the Mouth.

\section{The Formula of the Neck}

$\mathrm{By}$

\section{Dr. Shiro OGAWARA}

Director of St. Marianna Research Institute Professor of Showa Medical College

From one length, one circumference, three widths and one depth of the neck, the Formula of the Neck was originated, of which the quantitative measurements were:

1) Neck-length: the vertical distance to the top of the clavicle from the center of the protrusion of the mastoid process which is behind the auricula.

Vol. 28 No. 8〜9 
2) Neck-circumference: the horizontal circumference immediately below the larynx.

3) Neck-width I: the direct distance between the two centers of protrusion of the right and left mastoid processes.

4) Neck-width II. the right and left distances of that section which is the uniform hei" ght as the neck-circumference.

5) Neck-width III : the direct distance between the two points on the right and left sides of the neck which meet the line of circumference connecting the cervicale with the suprasternaie.

6) Neck-hepth: the front and rear distances of that section which is the uniform height as the neckcircumference.

From the above six quantitative measurements, the following eight indices were derived:

i) Neck index I (=Neck-width I.100/neck-length)

ii) Neck index II (=Neck-width II. L00/neck-length)

iii) Neck index III (=Neck-width III.100/neck-length)

iv) Neck-width index A (=Neck-width II.100/neck-width I)

v) Neck-width index B (=Neck-widtd III.100/neck-width I)

vi) Neck-width index C (=neck-width III.100/neck-width II)

vii) Neck circumference index ( $=$ Neck-length.100/neck-circumference)

viii) Neck-depth index ( $\doteq$ Neck-depth.100/neck-width II).

These indices were sought from the anthropological ages of many instances of men and women, and centered around their respective arithmetical averages, these indices were classified into five or six types taking into consideration standard variations and other factors.

These types were symbolized simply from one to five or six, and by using the letter "U" for the index in vii) above and the letter " $\mathrm{T}$ " for the index in viii) above, the numerical formula which was produced by charting the indices parallely in the order of I II III A B C U T was named the Formula of the Neck. 